\title{
THE IMPACT OF FOREIGN DIRECT INVESTMENT ON THE UNEMPLOYMENT RATE IN THE REPUBLIC OF SERBIA
}

\begin{abstract}
This paper analyzes the Republic of Serbia in the period of transition from a planned economy with special social, political and economic conditions towards an open economy through the inflow of FDI and their impact on the unemployment rate. Creating the conditions for an inflow of FDI started in order to increase the employment rate. Since 2000, most FDI had entered the sector of non-tradeable goods which led towards increasing unemployment. That has had negative effects on Serbia from the development viewpoint, since the country needs FDI in the sector of non-tradeable goods, as they encourage productivity, technological progress and employment. Foreign investors in Serbia were primarily interested in profiting from the privatization (brownfield investments) of former state-owned companies which led to the rationalization of the privatized companies through redundancies. The benefits that Serbia has had from the inflow of FDI are significant transfers of technology and enhancement of competition on the local market. On the other hand, negative effect is increase of the unemployment rate at the national level.
\end{abstract}

Key words: brownfield investments, FDI, greenfield investments, unemployment rate.

\section{Introduction}

Investments are one of the most important issues of macroeconomic policy of a state. Therefore it is very important to define and implement a clear and consistent policy in this sensitive and important area of social life. Economies in transition, such as Serbia and other states of Southeast Europe, in the absence of their own capital make decisions for "import of capital" to painlessly as possible

\footnotetext{
Aleksandar Stanković, student at PhD studies at Faculty of Business Studies, John Naisbitt University (Megatrend University), Belgrade, e-mail: aleksandarstankovic@yahoo.com

** Strahinja Kulić, student at PhD studies at Faculty of Business Studies, John Naisbitt University (Megatrend University), Belgrade, e-mail: strahinja.kulic@yahoo.com

*** Assistant Professor Dinko Primorac, PhD, Faculty of Business Studies, John Naisbitt University (Megatrend University), Belgrade, e-mail: primoracdinko@gmail.com
} 
change economic structure and make stable growth and development. A different choice, at least from their perspective, is almost non-existent. According to the International Monetary Fund, the SEE countries, including Serbia, need far more foreign direct investment. In the years of the global economic crisis, these expectations are difficult to achieve. Therefore, it is important to continue attracting foreign investment in order to increase economic growth, reduce unemployment, and increase standards of citizens and the like. Foreign investment can be of different types, on a case by case basis. Their insights require closer clarification of their essence and effects that can provide them. Therefore, the first task is to talk about disposition and types of investments and then on the effects that investments generate. This will provide more complete picture about the reasons that lead to foreign investment.

In transition economies, FDI affect directly the employment rate; primarily through privatization (brownfield investments) of existing companies, a decrease of the number of employees emerges due to the reduction of operating costs, while on the other hand, due to the opening of new businesses (greenfield investments), there is an increase in the number of employed.

\section{Theoretical background}

In the literature, there are different definitions of FDI. One of the more frequently used is given by Kindleberger, well known expert in the subject matter. In his opinion, foreign direct investment is a direct investment in the company abroad, in order to gain permanent control over that company's production, trade and finance. ${ }^{1}$ On the other hand, some authors point out that foreign direct investments provide long-lasting relationships and interests, as well as the possibilities of long-term and often permanent control of the organization in which foreign capital has been invested. ${ }^{2}$ It can be concluded that foreign investments are considered financial and other investment entities of one country in economic and organizations of other countries. As a rule, linked to the strengthening of economic and other capacities and job creation, the phenomenon of foreign direct investment can be viewed from two related but distinctly different aspects.

From a macroeconomic point of view, foreign investment represents a special form of movement of capital across borders of the national economy, from the country of the investor to the host country. It is registered in the capital account of the balance of payments. The importance of such a movement of capital is reflected in the increase of the capital stock in the host country. The capital value of company in which was invested significantly is increased. Macroeconomic aspect of

Jovanović - Gavrilović P. (2006): Međunarodno poslovno finansiranje, Ekonomski fakultet u Beogradu, Beograd, 100.

2 Kozomara J. (2001): Izvoz i uvoz robe, Ekonomski fakultet u Beogradu, Beograd, 29. 
observing a given phenomenon is focused to explaining the motivation for undertaking direct investment abroad, from the standpoint of investors. Among other things, it involves the study of reason, justification and consequences of taking such actions, behind which powerful multinationals usually stand. Any serious investment needs various analyzes and assessments of competent experts from different fields. It must be well weighed, and then undertaken. It should be noted that foreign direct investment often leads to a merger or an existing business in the host country with the parent company abroad. Merged company changes ownership structure, legal identity, a common and managerial structure. Also worth mentioning is the fact that of the total direct investment abroad in the last two decades, between $70 \%$ and $80 \%$ of them are implemented as mergers and acquisitions ${ }^{3}$.

Companies are opting for mergers and / or acquisitions to accelerate the process of conquering new markets by buying local businesses that already have worked out a business. This approach significantly reduces the risk of investment, which is not surprising as foreign transnational companies at the initial appearance in countries in transition, including the countries of Southeastern Europe, under the auspices of the privatization process extensively used these opportunities and benefits. Foreign companies in the host country open up entirely new business (opening of new factories, new production facilities, new branches and the like) that did not exist on the market. Foreign investor actually starts from the "greenfield", for which the State administration, often without any compensation, provides access to the infrastructure (electricity, gas, transport, etc.).This type of investment is known as greenfield investment. Such investment includes starting a business from scratch, building infrastructure, office space and attracting skilled staff. In any case, the choice of strategic alternatives is determined by the ratio of benefits and costs, regulation of the host country and the World Trade Organization. The company that implements the strategy of foreign direct investment has to make a series of decisions before start the realization of the same. The most important decisions that must be made at the same time are the choice of location and activity (horizontal, vertical and conglomerate), whose defining includes concrete activities (full production, part of the production, etc.), as well as the determination of the degree of legal independence ${ }^{4}$.

\subsection{Types of foreign investments}

There are different types of foreign investments. In the professional and scientific circles prevailing view is that there are three types of investments. These are ${ }^{5}$ :

Rakita B. (2006): Međunarodni biznis i menadžment, Ekonomski fakultet u Beogradu, Beograd, 338.

Bjelić P. (2002): Svetska trgovinska organizacija, Prometej, Beograd, 21.

Rakita B. (2006): Međunarodni biznis i menadžment, Ekonomski fakultet u Beogradu, Beograd, 320. 
- $\quad$ Foreign direct investment (FDI);

- International loans or lending;

- International portfolio investments.

The role and importance of each category of international capital movements have changed over time. The difference between them comes from the degree of impact of capital owners on use of funds invested. It is believed that direct investment emerges if an investor, who invested directly in the company, owns more than $10 \%$ of the ownership or voting rights of the company, regardless of whether the company operates in the public or private sector. There may be more such investors. Some of them may have less investment or ownership of the enterprise in which the investment is made, with a value less than $10 \% \mathrm{com}$ pared to the total value of the company.

Foreign direct investments are dominant form of foreign investment. Transnational companies decide to place capital abroad in the form of direct investment in order to be able to enter foreign markets more easily, enable access to specific resources and / or accelerate the efficiency of their operations. It is therefore no wonder that such companies are often investors of foreign capital in the enterprises abroad. It is interesting to point out that the largest flows of FDI are taking place between developed countries. For example, in 2002, foreign direct investments amounted to about 650 billion USD, of which about 460 billion USD or about 71\% went to other developed countries and about 162 billion USD, or about $25 \%$ to developing countries. In that year, the countries of Central and Eastern Europe invested a little more than $4 \%$ of invested capital in FDI. ${ }^{6}$ On the other hand, international lending through loan agreements has no significance it once had. Such a method of securing foreign investments was very strong, if not dominant in the first half of the Twentieth Century. However, its influence has diminished over time, for the reason that it is not necessary to explain, because it goes beyond the purpose of this work. And finally, portfolio investments include investments that ensure the ownership of the company to the extent of less than $10 \%$. In addition, these investments include deposits in the banks as well as financial investments in the securities, issued by the State or the private sector. Such investments are becoming increasingly relevant, particularly in recent years. It is also worth to point out that, according to the regulations of the Republic of Serbia, foreign investors are accorded national treatment in all areas, except in the area of production and trade of weapons, as well as in the field of insurance.

$6 \quad$ Jovanović Gavrilović P. (2006): Međunarodno poslovno finansiranje, Ekonomski fakultet u Beogradu, Beograd, 182. 


\subsection{The effects of foreign investments}

The effects of foreign investments are important, especially in underdeveloped countries and regions of the world. Positive effects of such investments are especially important for the countries of Southeastern Europe, as evidenced by numerous indicators. Of course, foreign investments are linked to certain disadvantages. This is of particular importance for the Republic of Serbia. Among other things, because it is well known that foreign investments do not always lead to the desired results.

Some authors reasonably point out that "foreign direct investment in modern developmental stage function as a key development factor and with international trade as the main mechanism for the globalization of the world economy or business enterprise"7. However, from the point of view of globalization, there is another angle. Industrialized countries try to avoid opening their markets for goods from developing countries, maintaining its import quotas for a multitude of products, from textiles to sugar, while insisting that developing countries open their markets for goods from wealthier countries ${ }^{8}$. In other words, developed countries take advantage of their position and power in order to protect maximally their own interests at the expense of small and poor countries and people.

\subsubsection{Positive effects}

In the era of global economic crisis, the importance of foreign direct investment as an engine of economic recovery and development of developing countries and countries in transition is most clearly evident. Among these countries are the SEE countries. They are characterized by shortages of capital, which is considered to be the main generator of economic prosperity. Foreign direct investment, unlike international lending, does not require repayment of principal and interest, and contributes to the stabilization of national currency, GDP growth and the improvement of balance of payments situation. Also, by hiring local labor, as a rule, under very favorable conditions for investors, FDI contributes to the reduction of the unemployment rate and to the increase of disposable income of local population. Collection of taxes from newly employed workers results in improved public revenue inflow aimed for health and pension funds, as well as budgets of local communities. Also, FDI involves starting a new business abroad. To be able to achieve such goal it is essential to make a technology transfer to the host country, which requires technical knowledge, but also skills in management and marketing. The above approach improves the way of doing business in the entire national economy. Ultimately, with the growing competitiveness of the entire economy, newly built capacities certainly provide better

Bjeli P. et al. (eds) (2002): Svetska privreda u informatičkoj eri, Institut za međunarodnu politiku i privredu, Beograd, 29.

$8 \quad$ Stiglic Dž. (2004): Protiv rečenosti globalizacije, SBM-x, Beograd, 21. 
supply of goods for domestic market. Surpluses are exported, and thus the competitive position of the host country is improved.

\subsubsection{Negative effects}

States that are final destination of foreign capital must take into account possible negative consequences of the process of internationalization of business. As an argument against FDI inflow there are allegations of unscrupulous exploitation of the workforce. Such reactions are not unique and are present all over the world. Although the opinions of the anti-globalizers can be questioned, we cannot refute the fact that their views are founded. It is another matter that the poor are not able to elect or to significantly affect the rules of the game.

Critics of foreign direct investment commonly stress the fact that such investments are actually providing technological dependence of domestic economy. In their favor is the fact that most of the world's powerful companies invest their capital being directed toward regions and countries with the lowest wages, as well as to countries in which the rights of employees are threatened. They argue that under the influence of foreign capital, especially when it comes to direct foreign investment, the economy evolves according to the needs and interests of foreigners, and not according to the needs and interests of local population'. Because of these concerns, economic policy makers are obliged to prevent distortion of domestic economic structure using appropriate decisions and to focus activities of multinational companies towards achieving the national macroeconomic objectives. It is more than clear that this is not taken sufficiently into account yet. The consequences of such a situation can be very serious, and endure in the long run. Special problem for the State and its administration is the need to ensure transparency of the market. This need is particularly evident in underdeveloped countries where international, economically powerful companies in the initial years of operations may by implementing dumping prices thus eliminating competition and then exploiting dominant position on the market. No one can benefit from such situation, except transnational companies.

The most radical critics of foreign direct investment suggest that such investments may even threaten the sovereignty of the State, as the people behind them have significant information that may be misused. On the other hand, there is thought to indicate that different fears arise as a result of the retrograde model of thinking and devoid of any foundation. One of the big problems is certainly the transfer of profits from a branch of the parent company. This leads to outflow of capital accumulated in the host country abroad. Legal and other regulations of the State tend to compress the above phenomenon, but numerous mechanisms are available to multinational companies that easily circumvent legal restrictions (for example, transfer pricing, etc.). The transfer of profits distorts the balance of

Jovanović Gavrilović P. (2006): Međunarodno poslovno finansiranje, Ekonomski fakultet u Beogradu, Beograd, 161. 
payments, and initial positive effects, resulting in inflow of capital, are sometimes completely neutralized.

One of the key motives of foreign companies to do business across national borders is certainly the exploitation of natural resources of the host country. Frequently it comes to renewable sources of energy and mineral resources, and the government must be very cautious in defining the concession contract. Similar reasoning can be applied when it comes to the use of infrastructure in whose building foreign companies have not participated (for example, connections to water, electricity, gas and the like; use of local roads, the use of local transmitters, etc.).

Although foreign capital plays an important role in promoting economic growth, economic policy makers must be aware of the fact that excessive expenditure in public spending could jeopardize the achievement of the positive effects of foreign direct investment ${ }^{10}$. This fact has constantly to be taken into account by competent authorities of the countries of Southeastern Europe if they want truly to protect their national and state interests. Even more so these countries are faced with the problem of excessive public spending for a long time.

\section{Foreign direct investments and the unemployment rate in the Republic of Serbia}

The value of foreign investments in the Republic of Serbia in the period from 2005 to 2012 is about 9.5 billion USD. The largest investment in the reporting period was in the period of 2005 - 2007 (more than 3 billion USD), and the lowest in 2012 ( 352 million USD). Considered by year, the value of foreign investments in the country is largest in 2011 and amounted to more than 2.7 billion USD. Although the value of such investments is not enough for Serbian economy, the fact is that without FDI unemployment rate in Serbia would be much higher, regardless of the fact that FDI does not always bring new jobs. In many cases, such investments are related to the purchase of domestic companies, which employ a large number of workers. Moreover, in such cases, the number of employees has not increased but usually decreased.

According to the forecasts of National Bank of Serbia (NBS), the EU accession process, government stability and structural reforms stimulate FDIs. In 2014, a net FDI inflow of EUR 1.2 billion was recorded, mostly in manufacturing, finance and trade. Most of the FDI came from EU (around 80\% of total), Russia (7\%) and Switzerland (3\%).FDI is projected at EUR 1.3 billion in 2015. Major part of inflows will target the manufacturing and trade sectors. FDI projections exclude potential privatization proceeds, some of which have been announced for 2015. Before the crisis, dominant share of FDI inflows was directed to the finance sector, as well as

10 Manh V. Le Terukazu S. (2005): "Foreign direct investment, public expenditure and economic growth: the empirical evidence for the period 1970-2012", GSICS Working Paper Series, no. 2, 2005, Kobe University. 
construction and real estate. In Q1-Q3 2014, the greatest share of gross FDIs was directed to the manufacturing (34.5\%) and finance industry (25.8\%). Since 2011, share of FDIs in the manufacturing industry has been steadily rising ${ }^{11}$.

Figure 1: The value of foreign investments in the Republic of Serbia in the period from 2005 to 2012

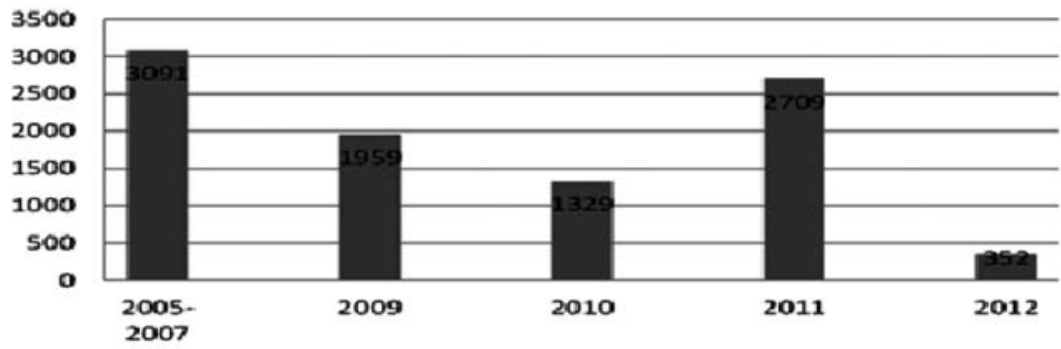

Source: UN World Investment Report 2013, http://unctad.org/en/PublicationsLibrary/ wir2013_en.pdf (19.3. 2015)

The unemployment rate in the Republic of Serbia is very high, especially in recent years. The causes for this are numerous. Among other things, these are: the process of privatization, permanent decreasing of accumulated capital and productivity of the economy, restrictive economic policies, unplanned personnel policy, negative tendencies in the field of population policies, brain drain, etc ${ }^{12}$.

Figure 2: The rate of unemployment in the Republic of Serbia for the period from 2008 to 2012

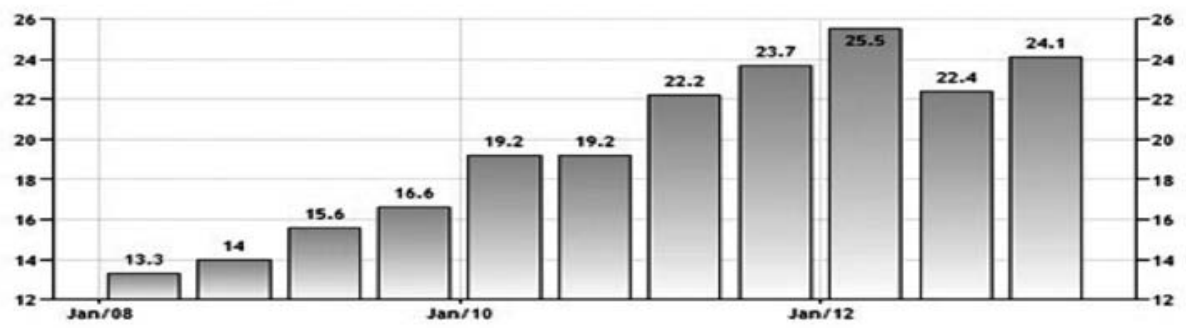

Source: Trading Economics, www.tradingeconomics.com (20.03.2015)

Figure 2.indicates that from 2008 to 2012, unemployment in Serbia is constantly growing. In the first half of 2008 it amounted to about $13.3 \%$, and in mid2012 was higher than $25.5 \%$. Although the effects of economic crisis contributed most to this condition it has been the consequence of other relevant factors, such National Bank of Serbia, www.nbs.rs (20. 3. 2015)

12 Milošević G. (2012): Osnove ekonomije, Kriminalističko-policijska akademija, Beograd, 264. 
as the failed privatization, rising crime and corruption, wrong economic policies, over-indebtedness of the domestic economy, and the like.

Figure 3: The employment situation in the Republic of Serbia in 2012 and 2013

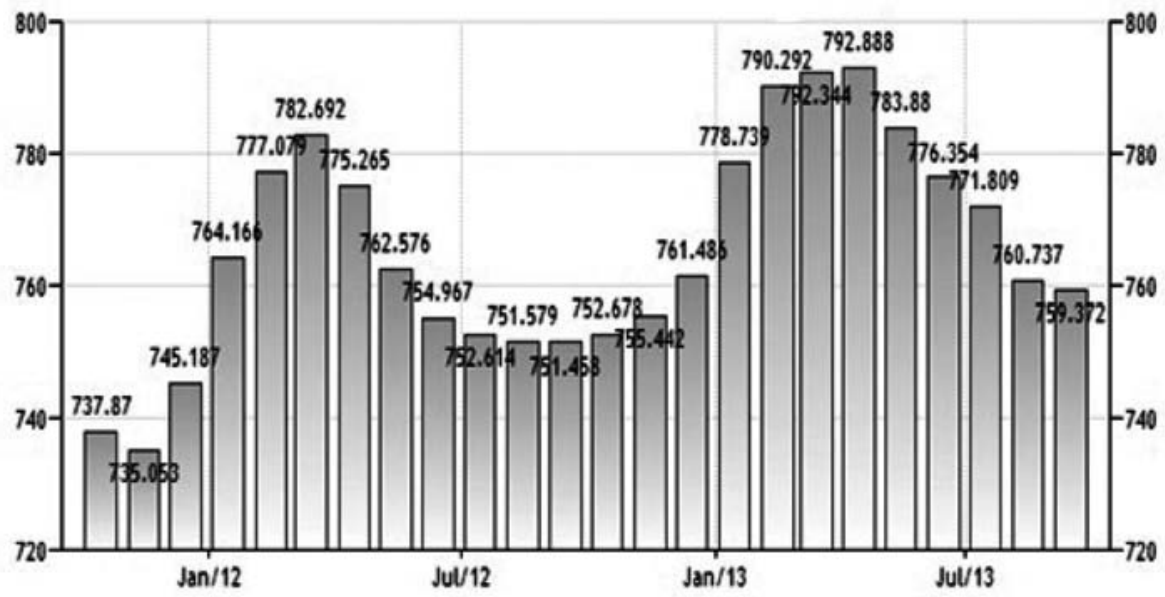

Source: Trading Economics, www.tradingeconomics.com (20.3. 2015)

On the basis of information contained in Figure 3 it can be concluded that unemployment is not reduced. On the contrary, there has been a slight increase. In the summer months, the situation is somewhat better, but during the fall and winter again it deteriorated and was returning to previous positions. All in all, it is obvious that unemployment in our country at this time (December 2013) is higher than ever in the past few decades.

Figure 4: The employment situation in the Republic of Serbia for the period from 2008 to $2012^{13}$

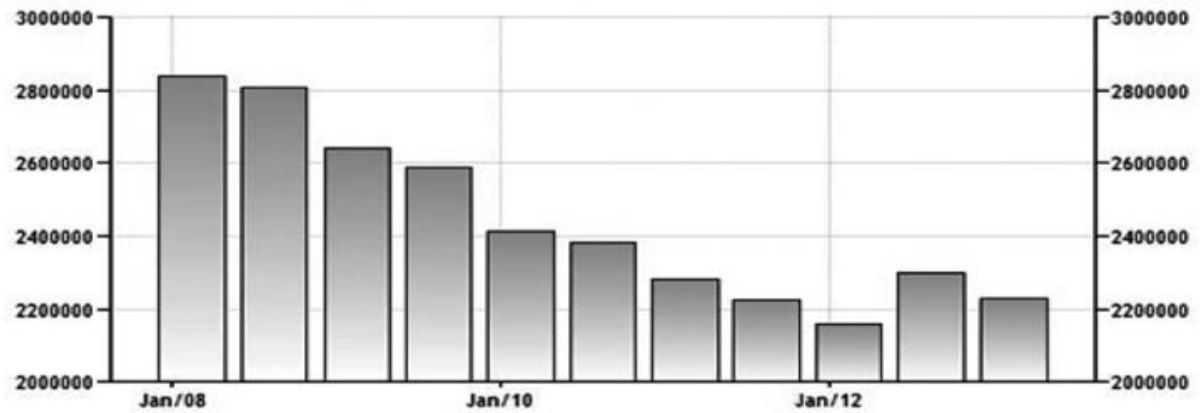

Source: Trading Economics, www.tradingeconomics.com (20. 3. 2015)

13 Trading Economics, www.tradingeconomics.com (20. 3. 2015) 
Data detained for Figure 4 testify to the fact that employment in the Republic of Serbia, in the reporting period, tends almost continuous decline. During few years, without job is more than 600 thousand people, which in a small and poor country like Serbia, represents irreparable loss.

\section{Conclusion}

Foreign direct investments should create new employment, to mitigate the transitional changes, also to lead to the introduction of new technologies and new management model, changing working habits, as well as to prevent brain drain from the country. Poorly executed privatization and inadequate use of funds that have flowed into the budget after privatization, as well as lack of foreign investment have led Serbia's unemployment rate to increase. In order to attract larger foreign direct investment and to influence the reduction of unemployment it is necessary to develop local entrepreneurship which will follow foreign investors because they usually seek for local partners. Failure to take steps towards the development of entrepreneurship on one side and use of comparative advantages based on cheap and highly qualified workforce as well as wealth of natural resources on the other side will not lead to a significant inflow of foreign direct investment. It will lead to an increase in the unemployment rate in the Republic of Serbia. The largest percentage of foreign direct investment in Serbia was related to privatization - the purchase of state-owned enterprises. Due to the rationalization of operations through relaxation redundancies from one side and due to the slow transfer of formally employed workers to real sector of economy on the other side the process of transition in Serbia led to a decrease in the number of employees in state-owned companies and consequently to a decline of formal employment.

Due to the lack of competitiveness of the national economy on a global level and direct foreign investment in non-exchangeable goods such as banking, telecommunications services and retail trade, the possibility for the absorption of surplus labor from the privatized companies was not created which directly increased the rate of unemployment. The inflows of FDI in Serbia have had a positive impact on economic growth, but not on exports. This has had negative effects on Serbia from the development viewpoint, since the country needs FDI to the sector of exchangeable goods because they encourage productivity and technological progress. This would absorb surplus labor from privatized enterprises and public administration, improve the trade balance, and create technological progress and competitiveness of the economy. Attracting greater foreign direct investments that are export-oriented, would stimulate productivity, technological progress, export, also would increase the competitiveness of local busi- 
nesses which directly leads to higher demand for labor. This would have a big impact on the reduction of unemployment in the Republic of Serbia.

\section{Literature}

- Bjelić P. (2002): Svetska trgovinska organizacija, Prometej, Beograd

- Bjelić, P. et al. (eds) (2002): Svetska privreda u informatičkoj eri, Institut za međunarodnu politiku i privredu, Beograd

- Jovanović Gavrilović P. (2006): Međunarodno poslovno finansiranje, Ekonomski fakultet u Beogradu, Beograd

- Kozomara J. (2001): Izvoz i uvoz robe, Ekonomski fakultet u Beogradu, Beograd

- Manh V. Le Terukazu S. (2005): „Foreign direct investment, public expenditure and economic growth: the empirical evidence for the period 1970-2001“, GSICS Working Paper Series, no. 2, Kobe University

- Milošević G. (2012): Osnove ekonomije, Kriminalističko-policijska akademija, Beograd

- National Bank of Serbia, www.nbs.rs (20.3. 2015)

- Primorac D. (2013): Poduzetništvo i poduzetnička orijentacija u Hrvatskoj, Srbiji i Bosni i Hercegovini, Megatrend University, Beograd

- Rakita B. (2006): Međunarodni biznis i menadžment, Ekonomski fakultet u Beogradu, Beograd, Srbija

- Stiglic Dž. (2004): Protiv rečenosti globalizacije, SBM-x, Beograd

- Skrtic M., Primorac D., Mikic M. (2015): Od ideje do realizacije poduzetničkog projekta, Univerzitet „Sjever“, Koprivnica, Hrvatska

- Trading Economics, www.tradingeconomics.com (20.3. 2015)

- Unković M. (2004): Savremena međunarodna trgovina, Beogradska knjiga, Beograd.

- UN World Investment Report 2013, http://unctad.org/en/PublicationsLibrary/ wir2013_en.pdf (19.3.2015) 
Aleksandar Stanković, student doktorskih studija

Fakultet za poslovne studije, Univerzitet „Džon Nezbit“

(Megatrend univerzitet), Beograd

Strahinja Kulić, student doktorskih studija

Fakultet za poslovne studije, Univerzitet „Džon Nezbit“

(Megatrend univerzitet), Beograd

\title{
Doc. dr Dinko Primorac
}

Fakultet za poslovne studije, Univerzitet „Džon Nezbit“

(Megatrend univerzitet), Beograd

\section{UTICAJ DIREKTINIH STRANIH INVESTICIJA NA STOPU NEZAPOSLENOSTI U REPUBLICI SRBIJI}

\begin{abstract}
S a $\check{z}$ e t a k
Ovaj rad analizira Republiku Srbiju u periodu tranzicije iz tržišno planske ekonomije, sa posebnim društvenim, političkim i ekonomskim uslovima, ka otvorenoj privredi, kroz priliv stranih direktnih investicija i njihovog uticaja na stopu nezaposlenosti, te stvaranje uslova za priliv SDI u cilju povećanja stope zaposlenosti. Od 2000. godine najviše SDI je ušlo u sektor uslužnih delatnosti, što je dovelo do povećanja nezaposlenosti. To je imalo negativne efekte na Srbiju s razvojne strane privrede, jer su zemlji potrebne SDI u sektoru proizvodnih delatnosti, uz podsticanje produktivnosti, tehnološki napredak i zapošljavanje. Strani investitori u Srbiji su prvenstveno zainteresovani za profitiranje od privatizacije (braunfild investicije) bivših državnih preduzeća, koja su doveli do racionalizacije kroz otpuštanja radnika. Prednosti koje Srbija ima od priliva SDI su značajan transfer tehnologije, kao i unapređivanje konkurencije na domaćem tržištu. S druge strane, negativni efekti su povećanje stope nezaposlenosti na nacionalnom nivou.
\end{abstract}

Ključne reči: braunfild investicije, SDI, grinfild investicije, stopa nezaposlenosti 